Proceedings of the 2018 International Scientific Conference 'Economic Sciences for Agribusiness and Rural Economy' No 2, Warsaw, 7-8 June 2018, pp. 313-318

\title{
KNOWLEDGE BASED ECONOMY: OPPORTUNITIES AND CHALLENGES
}

\author{
Anna Milewska, $\mathrm{PhD}^{1}$ \\ Faculty of Economic Sciences, Warsaw University of Life Sciences - SGGW
}

\begin{abstract}
Nowadays, we can observe in different business and academicals environments an ongoing dialog about knowledge - based economy, due to the fact, that economies are increasingly based on knowledge and information. Practically it means, that companies have started looking for answers for plenty important questions - what 'knowledge' exactly means and what kind of knowledge is significant from business continuity perspective? What exactly is a driver of productivity and economic growth? Business executives have to face also other challenges: how all this knowledge has to be managed and how to adapt to swiftly changing circumstances? Should it be centralized in shared services centres forms or maybe outsourced based on business process outsourcing strategy? Do companies should establish cooperation with universities or R\&D institutes based on the cluster structure? In this article the author will characterized the knowledge as a source of competitiveness, increasing importance of science and try to summarize best practices in that field.
\end{abstract}

Keywords: knowledge management, shared services centres, business process outsourcing JEL code: D83

\section{INTRODUCTION}

The notion of knowledge based economy has become popular in economic literature quite recently. Nevertheless, within last few years, this phenomenon of economic development connected with broad application of knowledge has gained momentum. Theoretical concept of knowledge based economy has appeared at the beginning of the 1990s. Its basis was seen in increasing importance of globalization and in the development of information technology. OECD report form 1996 became the first complex description of that phenomenon. According to this, it is a type of economy, which based on production, distribution as well as on usage of knowledge and information (OECD, 1999). The concept of knowledge based economy is also used interchangeably with 'new economy'. However, in literature, we can find many other examples: Drucker used the words 'post - capitalistic society' (Drucker, 1999) and Naisbitt -'society of knowledge' (Naisbitt, 1997). These phrases describe the same reality, nonetheless, they highlight different aspects, e.g.: the meaning of the network in the economy structure or the occurrence of radical changes in technologies connected with digitization.

${ }^{1}$ Corresponding author: Nowoursynowska 166, 02-787 Warsaw, Poland, anna_milewska1@sggw.pl, +4822 5934069 


\section{THEORETICAL BACKGROUND}

Creation of knowledge based economy depends on few favourable conditions, like set up and then constant development and growth of companies which based their competitive advantage on knowledge. These conditions are represented by state, local and regional authorities, industries, intellectual and academic environments. The competitive advantage built on knowledge has two conceptualizations: wider and narrower. The wider one, understands the knowledge as every unique and useful information, which the company exclusively has and owns as well as is able to use it to achieve and entrench its competitive advantage. In the narrower understanding, a unique knowledge is also the case, however it does not belong to that company - it is used on daily basis, but was not originally created by the company itself - so that it is not the company property (Koźmiński, 2002). The Institute of the World Bank defined the conditions, which each country should meet to become a part and start participating in the knowledge based economy (OECD, 2000):

1. Free flow of knowledge thanks to economic and institutional conditions, expanding the investments full of new information and communication technologies;

2. The society ought to either have or create necessary skills in the field of knowledge usage;

3. The country itself should dispose dynamic informational structure which helps effectively distribute and process information;

4. The existence of research centres, universities, teams of professional consultants, private investors and social groups able to use, assimilate and create new knowledge.

What is important in that concept, the country can support the development of knowledge based economy applying following initiatives (Orłowski, 2000):

1. Driving adequate macroeconomic and structural policy, focused on decreasing the current level of taxation for industries, increasing economy openness, effective privatization and restructuration;

2. Rationalizing the expenses on research and development;
3. Carrying about the education policy to improve the education quality and adjust the system to current economic needs. Due to this, the knowledge itself can be understood as a product as well as the growth factor. In the same time, it can be an object/subject of market turnover and the economic good. Knowledge is also the set of information necessary to make specified decisions.

\section{MATERIALS AND METHODS}

The article presents the overview of scientific literature focused on the subject of knowledge based economy, innovation, development and changes within the society. Meanwhile, the Author has been striving to get to know the specificity of knowledge based economy, the reasons behind its success or whether it is possible to make it grow by well - prepared society and state. Besides the scientific literature, the Author also presented the overview of European Union publications/statements (e.g.: National Strategy of Regional Development 2010 -2020), to picture the broader view of the subject and moreover, to show how the countries and industries can become a part of this economic change - beside the obstacles. Polish and international literature were used to create the comprehensive understanding of knowledge based economy phenomenon. Knowledge based economy has 3 faces (Skrzypek, 2009):

1. Methodological: it means searching new ways to identify analyse problems in the area of knowledge management;

2. Empirical: monitoring how the economy has been changing into knowledge based one as well as knowledge diffusion within societies and industries;

3. Pragmatic: what means creating and promoting the systems allow manage the knowledge at all levels of social life.

First of all, the Author focused on the theoretical part and review of literature and EU publications. Secondly, to present how the theory was applied into practise, the Author described 3 business examples of structures which fully meet requirements to be recognized as knowledge based features. 


\section{RESULTS}

Different scientist present the same concept of knowledge development - it is connected with next phases of development and progress of a mankind. Due to Bell, current era can be called 'post-industrial'. It has begun in the second half of the 21 st century and continues till today (Bell, 1973). The crucial role has the knowledge - understood as a specific resource which yields the meaning and forms new economy. Another example of distribution was created by Schumpeter and his continuers, Freeman and Soete (Schumpeter, 1960; Freeman and Soete, 1997). They split the development of humanity for 5 phases, so today, global society exist in the fifth phase. This phase was began by digital network and Internet. New products connected with modern technologies appeared on the market. Thanks to the Internet, time of the information flow as well as the distance ceased to be important. What is more, the new definition of the society occurred: information society, living in the world of growing importance of information, knowledge and innovations, common usage of ICT technologies, increasing number of employees whose intellectual potential is highly connected with economic success. That kind of society is characterised by exponential production growth, high level of media interference and the dependence of various aspects of human life on receiving and producing information (Fic and Fic, 2004). People belong to such society have 3 important attributes: accept competitiveness, require creativity and respect each other successes. It means, that due to the rate of changes, existing knowledge evolves in a very short time. People are forced to constantly develop their skills to adapt to this swiftly changing environment and achieve both - personal and organizational goals. Each person becomes representative of information society, a 'vehicle' of knowledge, wanted on the market - for the companies' such employees are a source of competitive advantage.

However, following Drucker, 'knowledge only' is not enough. Intellectuals need industries as a tools to enable them use their specialized skills. Knowledge - based organizations have a straight, ordered structure, directed at creating the added value thanks to the effective use of knowledge (Drucker, 2001). This understanding Drucker also presents in his definition of knowledge based economy as an economy based on pillars: innovative systems (creating financial, law and administrative conditions conductive to innovation), informational infrastructure and education and trainings (investment in the human capital, including continuous education).

The key competence for all companies to increase its efficiency is the ability to provide valuable information to its members. Efficient communication became the grates value (Dale, Cooper and Willkinson, 197). According to that, present industries are able to adapt better and quicker to market demands. They can offer their products and services at the lowest price and in the most comfortable way for buyers. Operating activity based on process standardization: supply, production, distribution are possible on the top level, if the whole process in standardised and well-coordinated. To achieve this perfection, proactive company culture needs to be establish: self - discipline of all members, great accuracy, desire to increase the productivity, frugality and matching the offer to individual customers' needs. To achieve the success as a company operating in the conditions of knowledge based economy, it has to understand and implement the following division of knowledge itself (Lundvall and Johnson, 1994): know - what: refers to facts and information, know - why: refers to understanding the rules working within the society and nature, know - how: refers to human abilities to do something collected in the form of experience, creates experts and know - who: it allows to use expert knowledge during production process.

Based on different metrics, researches and EU started new initiative: Europe Strategy 2020. In April 2011, all member states provided European Commission their National Reform Programs to accomplish the main Strategy goals: increase of the intellectual capital, sustainable development and social capital. Poland prepared the National Strategy of Regional Development 2010-2020: Regions, Cities, Rural Areas. Country decided to press ahead with unlocking development processes within a regions in line with the knowledge based economy bases. Development policy assumed launch of unused labour resources, absorption and creating innovations based on 
straightening the sector of research and development as well as activate their cooperation with companies, stimulate the growth of social capital, providing adequate technical and institutional conditions. What is more, this document presents also the changes in the employment sector to increase the number of people employed in the modern business structures. One of that structures is Shared Service Centre. This is a type of transnational way of managing the knowledge and business. Existing business functions, like HR, Administration, Finance, IT, Customer Service, Logistic etc. become concentrated into one place in the world, not necessarily in the country of origin and from that destination they are servicing the whole world. SSC promotes efficiency, cost savings, improve the service, however what is also important - it supports the knowledge transfer, modern management what finally increase the level of innovation and competitiveness. Based on the Poland example and ABSL report (Association of Business Service Leaders in Poland), currently, there are more than 600 SSCs, employing more than 200,000 people (Górecki et al., 2016). Growing number of SSCs means increasing requirement for well-educated and prepared employees. Why Poland is one the most popular location for SSCs in Europe? There is one reason behind - knowledge (the availability of highly educated resources). One of the main strengths of Polish specialists is the knowledge of foreign languages desired by employers. In this sense, Polish employees outperform other European countries and India, which so far was the most frequently chosen location for business processes outsourcing. Following the example, in June 2015, TNS research agency published the results of a survey conducted on 8-13 May 2015 on a representative, nationwide group of Poles aged 15 and more, using the CAPI method (Computer Assisted Personal Interview). According to the results, more than every third Pole declares knowledge of at least one foreign language, while the others can be qualified as polyglots using at least two foreign languages (Krassowska, 2015). Shared Service Centre structure is able to achieve of knowledge based economy goals: being professional, aware of international best practices and best information management methods, implement standardised, better process to complete the work, improve cross - group learning, constantly increase the quality, discover customers' needs and monitor the satisfaction, become more accessible and accurate.

Knowledge is also one of the main reasons behind creation of BPO structures - Business Process Outsourcing. It is a type of structure, where a third party provider is involved - the company $\mathrm{X}$ decides to outsource a chosen part if its business, like HR, IT, Customer Service outside to a company Y which will drive this activities and be responsible for them on daily basis for the company X, e.g.: Accenture is an example of BPO structure. Why it is connected with the knowledge based economy? Beside of the cost reduction, third party service provider, taking some basic, repeating processes and tasks, allows the main company to focus on the core competencies and what is more - on innovations - to achieve further operational excellence. The second advantage is the ability to reassign resources, both employees and space. Company can easily reallocate unleashed resources: people, time, money, office space, for additional improvements, project work, applying updated technologies. Next advantage of outsourcing is the access to the customer feedback: in most cases, BPO employees are in the direct contact with customers, so they are able to receive and gather a 'first - hand' feedback about the product and services. Refer to the customer feedback, companies are able also to improve the other sectors connected with production, like supply planning or logistic. The last example of the structure which meets all the requirements of the knowledge based economy is a cluster structure. Clusters are (mostly regional) concentrations of businesses including their service providers along a value chain. It is type of activity driven by at least 2 businesses, which take profits from cooperation with each other. The benefits are free flow of knowledge, experience, technologies and ideas between the partners. Each partner brings specific strengths to the alliance. Economic and country policies in most cases support cluster formations. According to data from the Catalogue of the Polish Agency for Enterprise Development 'Clusters in Poland', there are 14 Special Economic Zones operating in Poland, which allow entrepreneurs to conduct business activities on pref- 
erential terms, e.g.: thanks to tax relief, preparation of specially equipped land, etc. A good example of a cluster structure in Poland is the Nutribiomed cluster in the Lower Silesian Voivodship. The area of interests and activities of the cluster includes advanced technologies in food processing and biotechnology, cosmetics and pharmacy. Currently, the cluster includes six universities, three business environment institutions and more than thirty enterprises from the food, biotechnology and biomedical industry. In the international arena, NUTRIBIOMED cluster cooperates with partners from Italy, Hungary, Austria and the Czech Republic. To sum up, cluster initiatives not only contribute to the growth of enterprises' competitiveness and creation of new workplaces, knowledge, information and technologies flow, but also strengthen the position of a given country on the international arena.

\section{CONCLUSIONS}

The fundamentals of the knowledge based economy is a transition from the material economy to the economy which used the potential of the science and information. Intangible assets have gained the importance, especially human capital, knowledge and new technologies. According to that, the development will be more and more impacted by the intellectual potential as well as the latest achievements of the modern science. Growing competition which refers to creating and implementing innovations requires from the people constant development, adequate skillsets and adapting new knowledge.

However, following Toffler (1986), the development of knowledge based economy, may bring also different risks, for example fast technological progress can intensify the gap between poor, backward countries and the technically advanced ones. These countries, which are during the development process might be in danger - if they do not absorb the technological achievements quickly, that can be marginalized and standardization of products and services may increase the danger of market monopolization.

Unfortunately, the role which different solutions have been playing will be understood with time.
Sometimes, innovation can cause the creation of new social order, based on constant changes. Nevertheless, recognizing the benefits of change and agreement to their inevitability gives the chance to enter even more creative economic phase.

\section{REFERENCES}

1. Bell, D. (1973). The coming of Post - Industrial Society, Basic Books, New York.

2. Dale, B.G., Cooper, C.L., Willkinson, A. (1997). Managing Quality \& Human Resources. Blackwell, Oxford.

3. DiS (2008). Przegląd 300 międzynarodowych centrów usług: definicje, segmentacja, zatrudnienie, planu i prognozy (2008) [Overview of 300 international service centers: definitions, segmentation, employment, plan and forecast]. Warszawa. Retrieved: https://www.paih.gov.pl/files/?id_plik=10380 [Accessed 05.03.2018].

4. Drucker, P. (1999). Społeczeństwo pokapitalistyczne [Post-capitalist society]. PWN, Warszawa.

5. Drucker, P. (2001). The next Society: a Survey of the Near Future. The Economist of 03.11.2001.

6. Fic, M., Fic, D. (2004). Partnerstwo w społeczeństwie wiedzy [Partnership in the knowledge society]. In: Stosunki gospodarcze Unii Europejskiej. Wybrane kierunki polityki wspólnotowej [Economic relations of the European Union. Selected directions of policy]. Uniwersytet Zielonogórski, Zielona Góra, p. 270.

7. Freeman, C., Soete, L. (1997). The economics of Industrial Innovation. 3rd ed. Printer, London and Washington.

8. Górecki, J., Gurszyńska, K., Karpiesiuk, Ł., Polkowski, M. (2016). Sektor Nowoczesnych Usług Biznesowych w Polsce [The Modern Business Services Sector in Poland]. Raport ABSL. Warszawa.

9. Koźmiński, A. (2002). Jak zbudować gospodarkę opartą na wiedzy? [How to create a knowledge-based economy? Rozwój polskiej gospodarki. Perspektywy i uwarunkowania [The development of the Polish economy. Perspectives and conditions]. Wyższa Szkoła Przedsiębiorczości i Zarządzania im. Leona Koźmińskiego, Warszawa.

10. Krajowa Strategia Rozwoju Regionalnego 2010-2020. Regiony, miasta, obszary wiejskie [National Strategy for Regional Development 2010-2020. Regions, Cities, Rural Areas]. Ministerstwo Rozwoju Regionalnego, Warszawa. Polish Official Gazette 2010 No 36, item 423 . 
11. Krassowska, U. (2015): Znajomość języków obcych. Raport TNS Polska [Knowledge of foreign languages. TNS Polska report]. Warszawa.

12. Lundvall, B., Johnson, B. (1994). The Learning Economy. Journal of Industry Studies, 1 (2), 23-42. Retrieved from: https://www.researchgate.net/publication/227347297_ The_Learning_Economy [Accessed 16.05.2018].

13. Naisbitt, J. (1997). Megatrendy. Dziesięć nowych kierunków zmieniających nasze życie [Megatrends. Ten New Directions Transforming Our Lives]. Zysk i Spółka, Poznań

14. OECD (2000). Zarządzanie wiedzą w społeczeństwie uczącym się [Knowledge management in a learning socjety]. Centrum Badań nad Edukacją i Innowacją, OECD - Organizacja Współpracy Gospodarczej i Rozwoju, Ministerstwo Gospodarki, Departament Strategii Gospodarczej, Warszawa.

15. Orłowski, W. (2000). Knowledge Economy and Knowledge - Based Growth: Some Issues in a Transition Economy: The Knowledge - Based Economy: The European Challenges of the 21st Century State Commitee for Scientific Research of the Republic of Poland, Warszawa.

16. Polska Agencja Rozwoju Przedsiębiorczości (2012). Klastry w Polsce, Katalog [Clusters in Poland, Catalog]. 1st ed. Wydawnictwo PARP, Warszawa.
17. Scheer, G., Zallinger, L. (2007). Cluster Management A Practical Guide. Part A: Overview. Ministry of Economy, Labor and Entrepreneurship of the Republic of Croatia and the Deutsche Gesellschaft für Technische Zusammenarbeit (GTZ) GmbH, Germany. Retrieved from: https://www.clusterportal-bw.de/.../cluster-management-a-practical... [Accessed 16.05.2018].

18. Schumpeter, J. (1960). Teoria rozwoju gospodarczego [Theory of economic development]. PWN, Warszawa.

19. Schwartz, P., Kellyand, E., Boyer, N. (1999). The emerging global knowledge economy: The Future of the Global Economy. Towards a Long Boom? OECD, Paris. Retrieved from: https://www.oecd.org/futures/35394025.pdf [Accessed 11.05.2018].

20. Skrzypek E. (2008). Miejsce i znaczenie wiedzy w zrównoważonym rozwoju [Place and importance of knowledge in sustainable development]. In: Filozofia TQM w zrównoważonym rozwoju [TQM's philosophy in sustainable development]. Politechnika Radomska, Radom, pp. 158-165.

21. Toffler, A. (1986). Trzecia fala [The third wave]. PIW, Warszawa. 